\title{
Comparative Wood Anatomy in Pinaceae with Reference to Its Systematic Position
}

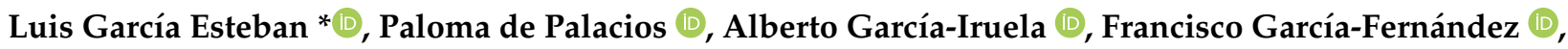 \\ Lydia García-Esteban and David González de Vega
}

Departamento de Sistemas y Recursos Naturales, Escuela Técnica Superior de Ingeniería de Montes, Forestal y del Medio Natural, Universidad Politécnica de Madrid, Ciudad Universitaria, s/n, 28040 Madrid, Spain; paloma.depalacios@upm.es (P.d.P.); agiruela17@gmail.com (A.G.-I.); francisco.garcia@upm.es (F.G.-F.); lydia.garcia@upm.es (L.G.-E.); dm.gonzalezdevega@alumnos.upm.es (D.G.d.V.)

* Correspondence: luis.garcia@upm.es; Tel.: +34-91-067-1751

Citation: García Esteban, L.; de Palacios, P.; García-Iruela, A.; García-Fernández, F.; García-Esteban, L.; González de Vega, D. Comparative Wood Anatomy in Pinaceae with Reference to Its Systematic Position. Forests 2021, 12, 1706. https:// doi.org/10.3390/f12121706

Academic Editor: Cristina Nabais

Received: 10 November 2021 Accepted: 3 December 2021 Published: 5 December 2021

Publisher's Note: MDPI stays neutral with regard to jurisdictional claims in published maps and institutional affiliations.

Copyright: (c) 2021 by the authors. Licensee MDPI, Basel, Switzerland. This article is an open access article distributed under the terms and conditions of the Creative Commons Attribution (CC BY) license (https:// creativecommons.org/licenses/by/ $4.0 /)$.

\begin{abstract}
The wood anatomy of 132 species of the genera Abies, Cathaya, Cedrus, Keteleeria, Larix, Nothotsuga, Picea, Pinus, Pseudolarix, Pseudotsuga and Tsuga was studied to determine the elements that characterise the xylem of each genus and discuss possible groupings by wood anatomy for comparison with clades established by molecular phylogeny. The presence of resin canals and ray tracheids supports the family Pinaceae, although the absence of ray tracheids in Keteleeria and their occasional presence in Abies and Pseudolarix weakens it. Based on wood structure, Pinaceae clearly supports division into two groups, coinciding with molecular phylogeny: Pinoideae (Cathaya-Larix-PiceaPinus-Pseudotsuga) and Abietoideae (Abies-Cedrus-Keteleeria-Nothotsuga-Pseudolarix-Tsuga). Although differences between genera are slight in Pinoideae, the Abietoideae group presents problems such as the presence of only axial resin canals in Keteleeria and Nothotsuga, absence of ray tracheids in Keteleeria and presence of traumatic radial resin canals in Cedrus. However, other features such as pitted horizontal walls and nodular end walls of ray parenchyma cells, indentures, scarce marginal axial parenchyma and presence of crystals in ray parenchyma strengthen the Abietoideae group.
\end{abstract}

Keywords: Abietoideae; anatomy; Laricoideae; phylogeny; Piceoideae; Pinaceae; Pinoideae; wood

\section{Introduction}

The family Pinaceae, consisting of 11 genera and 236 species, is the largest conifer family [1]. Traditional botanical classifications, such as that by Frankis [2] and Farjon [3] based on the morphological structure of vegetative and reproductive organs, include four subfamilies: Pinoideae (Pinus L.), Piceoideae (Picea A.Dietr.), Laricoideae (Cathaya Chun \& Kuang, Larix Mill., Pseudotsuga Carrière) and Abietoideae (Abies Mill., Cedrus Mill., Keteleeria Carrière, Nothotsuga Hu ex C.N.Page, Pseudolarix Gordon, Tsuga Carrière).

Using the comparative anatomy of the canals in leaves, bark and wood, $\mathrm{Wu}$ and $\mathrm{Hu}$ [4] subsequently divided Pinaceae into three groups: Cathaya, Larix, Picea, Pinus and Pseudotsuga, with normal resin canals; Abies, Cedrus, Pseudolarix and Tsuga without normal resin canals; and Keteleeria, with or without normal resin canals. Lin et al. [5], after confirming the constant presence of axial resin canals in mature wood of Keteleeria and the arrangement of traumatic resin canals in this genus, proposed a classification of Pinaceae in three groups, more in line with the wood anatomy of the family: Cathaya, Larix, Picea, Pinus and Pseudotsuga with radial and axial resin canals; Keteleeria and Nothotsuga with only axial resin canals; and Abies, Cedrus, Pseudolarix and Tsuga, without resin canals.

The wood structure of Pinaceae has been widely studied both at the genus and species level (e.g., [5-15]). Comparative anatomy studies of the wood of this family have dealt with the presence/absence of resin canals (both normal and traumatic) and their arrangement, and elements of the rays (horizontal and end walls of ray parenchyma 
cells, cross-field pitting, ray tracheids), axial parenchyma typology (presence/absence, arrangement, smooth/nodular transverse end wall), axial tracheids (presence/absence of helical thickenings, organic deposits in tracheids, warty layer) and the presence of crystals $[4,5,8,16-20]$.

Molecular phylogenetic studies have demonstrated the existence of clades among these genera [21,22] which either agree or disagree with groupings established by wood anatomy.

New studies of this type can reveal new relations between clades constructed based on molecular phylogeny and common anatomical features at genus level.

The objective of this study was to compare the wood anatomy of the family Pinaceae and discuss possible groupings of genera based on their anatomical features using the samples studied and with reference to the numerous studies on conifer anatomy, in order to compare these groupings with the clades established by molecular phylogeny.

\section{Materials and Methods}

The material used in this study came from the wood collections of ten research centres. A study was made of the wood anatomy of 132 taxa: Abies ( 35 spp. +1 subsp. +3 var.), Cathaya (1 spp.), Cedrus (4 spp.), Keteleeria (3 spp.), Larix (7 spp.), Nothotsuga (1 spp.), Picea (13 spp. + 1 var.), Pinus (48 spp. + 1 subsp. + 2 var.), Pseudolarix (1 spp.), Pseudotsuga (2 spp. +1 var.) and Tsuga (8 spp.). Appendix A lists the species with references to the collections from which the samples were obtained [23].

Microscopic slides were prepared in accordance with accepted methods of softening, microtome cutting to a thickness of $10-15 \mu \mathrm{m}$, staining and mounting. Samples were observed before and after staining with safranine and Sudan 4 to make the resin red [24]. The descriptions follow the recommendations of the IAWA Committee [25]. Samples were observed using light microscopy and scanning electron microscopy (SEM), model JEOL JSM-6380.

\section{Results and Discussion}

Summary of features by genus of Pinaceae based on the species studied is given in Table 1. Appendix B Table A1 shows the 132 taxa analysed with their particular features.

\subsection{Resin Canals}

The presence of resin canals in conifers is restricted to Pinaceae. Cathaya, Larix, Picea, Pinus and Pseudotsuga have both axial and radial resin canals (Figure 1A,B). Keteleeria, according to Lin et al. [5], has only axial resin canals, which generally have associated subsidiary tissue (Figure 1C). Normal axial resin canals have been recorded in Nothotsuga by other authors [11], although none were observed in the sample studied, probably because the wood was juvenile and this type of wood has very few resin canals. Abies, Cedrus, Pseudolarix and Tsuga do not have normal resin canals (Figure 1D).

Although in Pinus only thin-walled epithelial cells were observed (Figure 1E), resin canals in Cathaya, Keteleeria, Larix, Picea and Pseudotsuga had thick-walled epithelial cells (Figure 1F). Jin-Xing et al. [11] also reported thick epithelial in Nothotsuga. Moreover, axial resin canals in Pinus were usually larger and more numerous than in the other taxa.

Traumatic axial resin canals were observed in all genera studied except in the samples of Pseudolarix and Nothotsuga, although they were cited by $\mathrm{Wu}$ and $\mathrm{Hu}$ [4] as a response to wounding. In all cases, the traumatic resin canals were arranged in tangential rows and their diameter was greater than in normal resin canals. 
Table 1. Summary of features by genus based on the species studied. + Present, - Absent, (+) Occasional.

\begin{tabular}{|c|c|c|c|c|c|c|c|c|c|c|c|c|}
\hline & & Pinoideae & Piceoideae & & Laricoide & & & & Abi & toideae & & \\
\hline & & Pinus & Picea & Cathaya & Larix & Pseudotsuga & Abies & Cedrus & Keteleeria & Nothotsuga & Pseudolarix & Tsuga \\
\hline \multirow{4}{*}{ Tracheids } & $\begin{array}{c}\text { Organic deposits in heartwood } \\
\text { tracheids }\end{array}$ & $(+)^{1}$ & - & - & - & - & $(+)^{1}$ & - & $(+)^{1}$ & - & - & - \\
\hline & Helical thickenings & - & $(+)^{1}$ & + & $(+)^{1}$ & $(+)^{1}$ & - & - & - & - & - & - \\
\hline & Torus scalloped & - & - & - & - & - & - & + & - & - & - & - \\
\hline & Warty layer & - & - & - & - & - & + & + & - & + & - & + \\
\hline $\begin{array}{l}\text { Axial } \\
\text { parenchyma }\end{array}$ & Transverse end walls nodular & - & + & + & + & + & + & + & + & + & + & + \\
\hline \multirow[t]{11}{*}{ Rays } & Permanent ray tracheids present & + & + & + & + & + & - & + & - & + & - & + \\
\hline & Smooth ray tracheids & + & + & + & + & + & $(+)$ & + & - & + & $(+)$ & + \\
\hline & Dentate ray tracheids & + & - & - & - & - & - & - & - & - & - & - \\
\hline & Reticulate ray tracheids & + & - & - & - & - & - & - & - & - & - & - \\
\hline & Helical thickenings in ray tracheids & - & $(+)^{1}$ & + & - & $(+)^{1}$ & - & - & - & - & - & - \\
\hline & $\begin{array}{l}\text { End walls of ray parenchyma cells } \\
\text { pitted }\end{array}$ & $(+)^{1}$ & + & + & + & + & + & + & + & + & + & + \\
\hline & Pinoid & + & - & - & - & - & - & - & - & - & - & - \\
\hline & Window-like & + & - & - & - & - & - & - & - & - & - & - \\
\hline & Piceoid & - & + & + & + & + & + & + & + & - & + & + \\
\hline & Cupressoid & - & - & - & - & - & - & - & + & + & - & + \\
\hline & Taxodioid & - & - & - & - & - & + & + & + & + & + & - \\
\hline \multirow[t]{3}{*}{$\begin{array}{l}\text { Intercellular } \\
\text { canals }\end{array}$} & Axial resin canals & + & + & + & + & + & - & - & + & $+{ }^{2}$ & - & - \\
\hline & Radial resin canals & + & + & + & + & + & - & - & - & - & - & - \\
\hline & Thick-walled epithelial cells & - & + & + & + & + & - & - & + & +2 & - & - \\
\hline
\end{tabular}


Table 1. Cont.

\begin{tabular}{|c|c|c|c|c|c|c|c|c|c|c|c|c|}
\hline & & Pinoideae & Piceoideae & & Laricoide & & & & Abi & toideae & & \\
\hline & & Pinus & Picea & Cathaya & Larix & Pseudotsuga & Abies & Cedrus & Keteleeria & Nothotsuga & Pseudolarix & Tsuga \\
\hline & Thin-walled epithelial cells & + & - & - & - & - & - & - & - & - & - & - \\
\hline & Traumatic axial resin canals & + & + & + & + & + & + & + & + & +3 & +3 & + \\
\hline & Traumatic radial resin canals & + & + & + & + & + & - & + & - & - & - & - \\
\hline $\begin{array}{l}\text { Mineral } \\
\text { inclusions }\end{array}$ & Crystals & + & - & - & - & - & + & + & + & + & + & + \\
\hline
\end{tabular}

${ }^{1}$ see species in Appendix B Table A1, ${ }^{2}$ reported by Jin-Xing et al. [11]; ${ }^{3}$ reported by Wu and $\mathrm{Hu}$ [4]. 


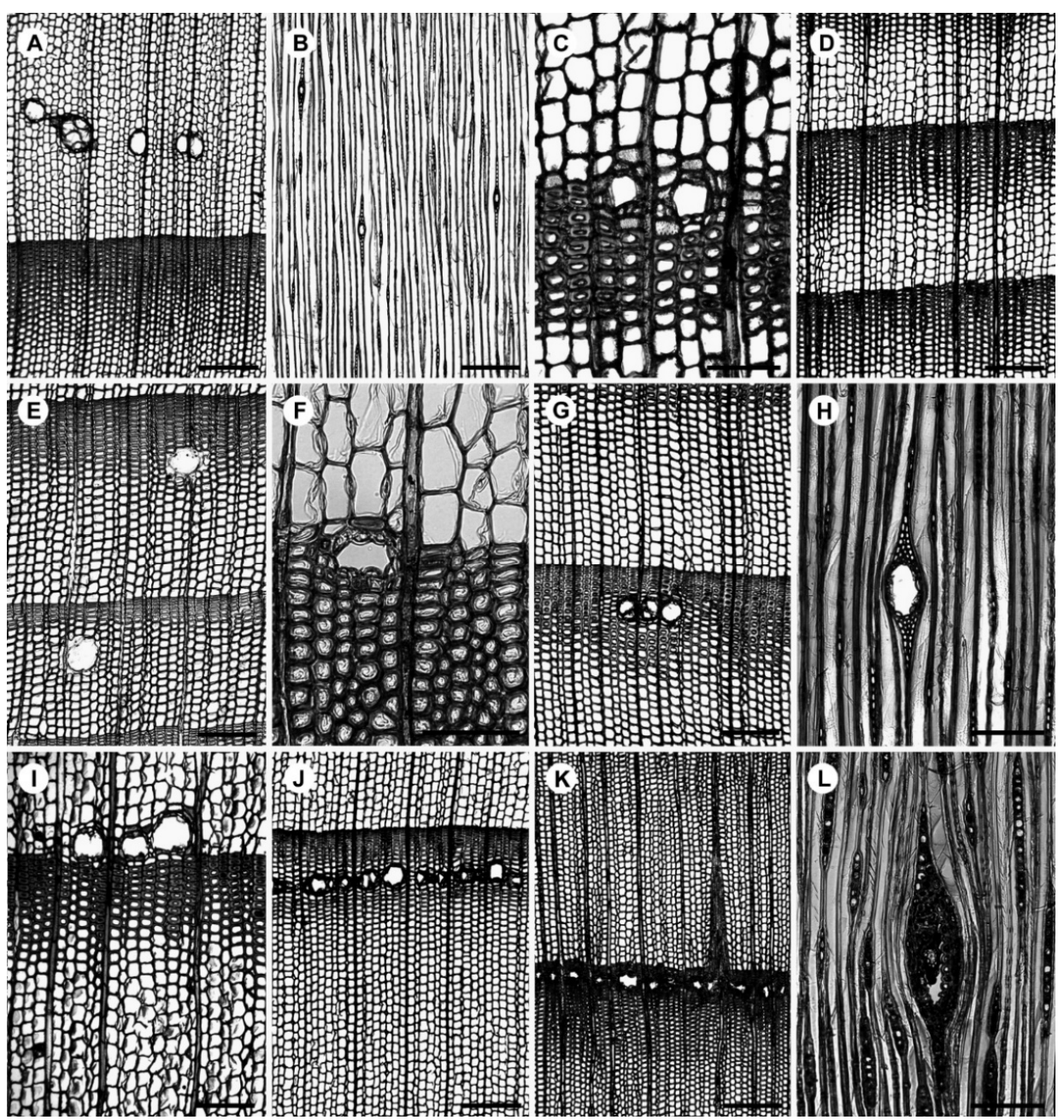

Figure 1. Resin canals. (A) Axial resin canals Picea koraiensis. (B) Radial canals Picea koraiensis. (C) Axial resin canals Keteleeria davidiana. (D) Without resin canals Tsuga diversifolia. (E) Axial resin canals with thin-walled epithelial cells Pinus resinosa. (F) Axial resin canal with thick-walled epithelial cells Larix kaempferi. (G) Traumatic axial resin canals Picea abies. (H) Traumatic radial resin canal Picea abies. (I-K) Traumatic axial resin canals. (I) Keteleeria fortunei. (J) Abies nephrolepis. (K) Cedrus brevifolia. (L) Traumatic radial resin canal Cedrus brevifolia. Scale bars: in $(\mathbf{F})=100 \mu \mathrm{m}$, in $(\mathbf{C}, \mathbf{G}, \mathbf{L})=150 \mu \mathrm{m}$, in $(\mathbf{A}, \mathbf{B}, \mathbf{D}, \mathbf{E}, \mathbf{H}-\mathbf{K})=250 \mu \mathrm{m}$.

Cathaya, Larix, Picea, Pinus and Pseudotsuga had both axial and radial traumatic resin canals (Figure 1G,H). In Keteleeria and Nothotsuga traumatic resin canals were only axial and appeared randomly and in tangential rows (Figure 1I), differentiating this genus from the others, in which traumatic resin canals were always arranged in tangential rows (Figure 1J). Jin-Xing et al. [11] suggested that Keteleeria and Nothotsuga have a high level of affinity due to the presence of axial resin canals in latewood and resin cavities in the bark. Cedrus follows a different pattern from the other genera without normal resin canals, as it is the only genus capable of forming both traumatic axial (Figure 1K) and radial (Figure 1L) resin canals. Molecular phylogenetic studies have shown that of the six Abietoideae genera, only Cedrus is difficult to include in the clade [22].

The presence of normal resin canals, therefore, allows three groups to be established: Cathaya-Larix-Picea-Pinus-Pseudotsuga, with axial and radial resin canals; KeteleeriaNothotsuga, with only axial resin canals; and Abies-Cedrus-Pseudolarix-Tsuga, without resin canals. The groups established by the presence of traumatic axial resin canals are: CathayaLarix-Picea-Pinus-Pseudotsuga, with both normal and traumatic axial and radial resin canals; Keteleeria-Nothotsuga, in which traumatic resin canals are only axial, in conjunction with 
normal resin canals, similarly only axial; Abies-Pseudolarix-Tsuga, with only traumatic axial resin canals and no normal resin canals; and Cedrus, with traumatic axial and radial resin canals but without normal resin canals.

\subsection{Rays}

Ray cell composition has been used as an essential element for classifying conifer families [26]. Ray tracheids always occurred in Pinoideae (Pinus) (Figure 2A), Piceoideae (Picea) (Figure 2B) and Laricoideae (Cathaya, Larix, Pseudotsuga) (Figure 2C). In Abietoideae ray tracheids are present in Cedrus (Figure 2D), Nothotsuga (Figure 2E) and Tsuga (Figure 2F), while in Abies and Pseudolarix they are rarely present. Only Keteleeria has no ray tracheids, which was confirmed in the samples studied (Figure 2G).
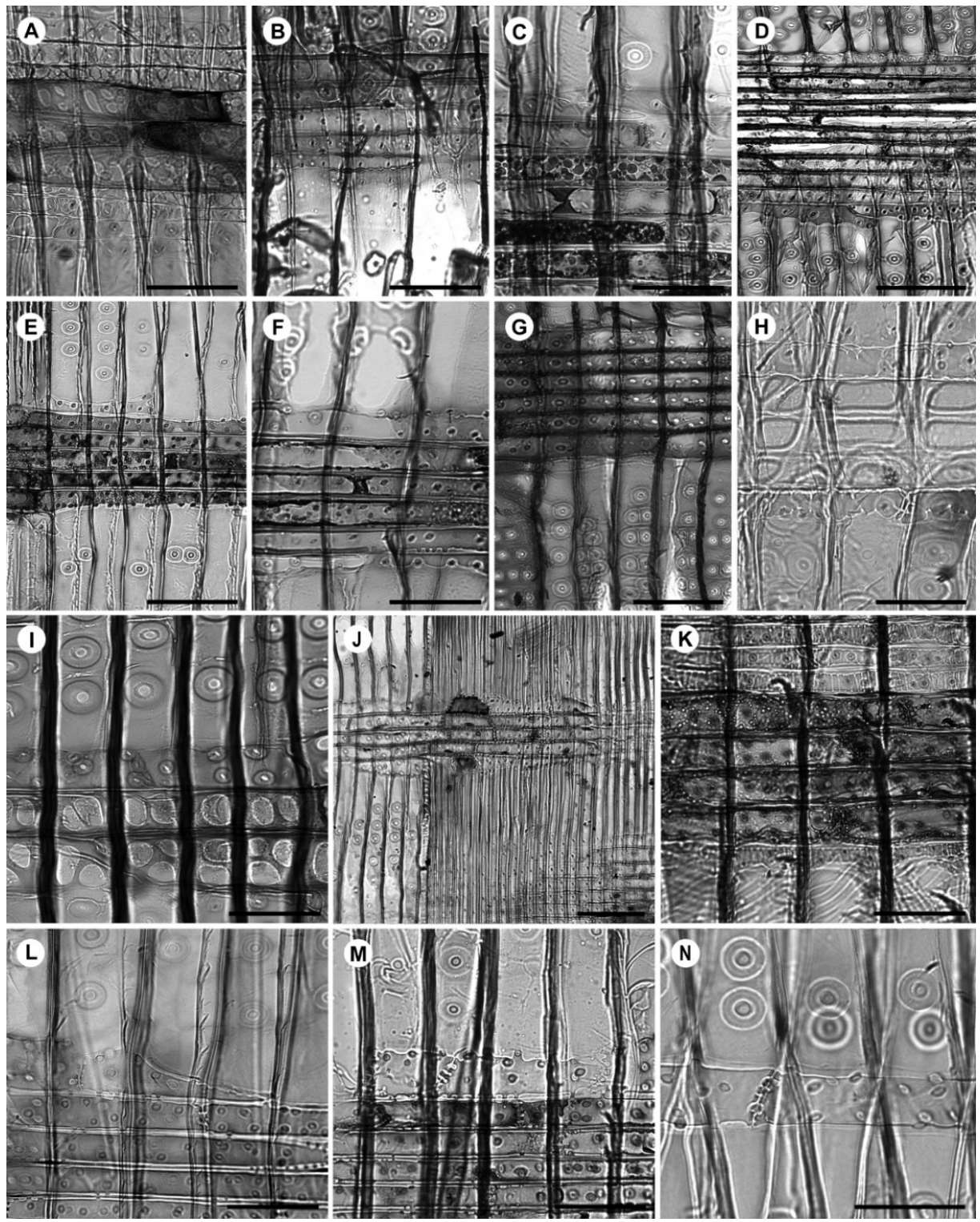

Figure 2. Rays. (A-I) Ray tracheids. (A) Pinus echinata. (B) Picea alcoquiana. (C) Larix occidentalis. (D) Cedrus atlantica. (E) Nothotsuga longibracteata. (F) Tsuga diversifolia. (G) Ray tracheids absent Keteleeria davidiana. (H) Dentate ray tracheids Pinus resinosa. (I) Smooth ray tracheids Pinus wallichiana var. wallichiana. (J) Irregularly shaped marginal ray cells Cedrus libani. (K) Helical thickenings in ray tracheids Pseudotsuga sinensis. (L-N) Ray parenchyma. (L) Pitted horizontal walls Abies nephrolepis. (M) Nodular end walls Abies nordmanniana subsp. equi-trojani. (N) Indenture Abies vejari. Scale bars: in $(\mathbf{A}-\mathbf{C}, \mathbf{F}, \mathbf{H}, \mathbf{I}, \mathbf{K}-\mathbf{N})=50 \mu \mathrm{m}$, in $(\mathbf{D}, \mathbf{E}, \mathbf{G})=100 \mu \mathrm{m}$, in $(\mathbf{J})=150 \mu \mathrm{m}$. 
Three types of ray tracheids have been differentiated in Pinus: smooth (P. armandii, P. ayacahuite, P. brutia, P. cembra, P. cembroides, P. gerardiana, P. griffithii, P. halepensis, P. hartwegii, P. koraiensis, P. merkusii, P. monophylla, P. morrisonicola, P. parviflora, P. peuce, P. pinea, P. quadrifolia, P. strobus, P. wallichiana) (Figure 2I), dentate (P. arizonica, P. banksiana, P. brutia, P. canariensis, P. caribaea, P. cembroides, P. contorta, P. densiflora, P. devoniana, P. douglasiana, P. elliottii, P. gerardiana, P. griffithii, P. halepensis, P. hartwegii, P. heldreichii, P. jeffreyi, P. kesiya, P. lawsonii, P. leiophylla, P. massoniana, P. maximinoi, P. merkusii, P. monophylla, P. montezumae, P. mugo, P. nigra, P. palustris, P. pinaster, P. pinea, P. ponderosa, P. pseudostrobus, P. quadrifolia, P. radiata, P. resinosa, P. rigida, P. sylvestris, P. tabuliformis, $P$. taeda, $P$. tecunumanii, $P$. teocote, $P$. thunbergii, P. tropicalis) (Figure $2 \mathrm{H}$ ) and reticulate (P. arizonica, P. banksiana, P. caribaea, P. contorta, P. devoniana, P. douglasiana, P. elliottii, P. heldreichii, P. jeffreyi, P. maximinoi, P. palustris, P. ponderosa, $P$. rigida, $P$. taeda, $P$. tecunumanii). Due to variability within the genus, this feature does not allow intergeneric groupings to be established in Pinaceae, but it has been used by other authors [27] to establish groups in Pinus.

Some authors explained the presence of ray tracheids associated with wounding $[7,28]$, as occurs with the presence of traumatic resin canals, although Holden [26] reported the presence of traumatic axial canals and the absence of ray tracheids as a response to wounding in Keteleeria. This absence of ray tracheids in Keteleeria disagrees with the clade proposed in the molecular phylogenetic study by Wang et al. [29], who concluded that the clade Abies-Keteleeria-Pseudolarix-Tsuga was well resolved.

Ray tracheids normally occur in marginal arrangement in one row (Abies, Cathaya, Cedrus, Nothotsuga, Pseudolarix, Pseudotsuga, Tsuga), in two or three rows (Larix, Picea), or in several marginal cell rows and occasionally in alternate rows (Pinus).

In Cedrus, especially in marginal rows, irregularly shaped cells have been observed (Figure 2J), described by Chrysler [30] as degenerated cells, although they are actually irregularly shaped ray parenchyma cells.

Helical thickenings in ray tracheids have been observed only in Cathaya, Picea spinulosa, P. torano and Pseudotsuga sinensis (Figure $2 \mathrm{~K}$ ).

Taking into account the presence of ray tracheids and their characteristics, a single group can, therefore, be established of the genera in which ray tracheids are always present Cathaya-Cedrus-Larix-Nothotsuga-Pinus-Picea-Pseudotsuga-Tsuga, in addition to AbiesPseudolarix, where they are occasionally present. Keteleeria is the only genus remaining outside this group and its inclusion is, therefore, unresolved.

Pitted horizontal (Figure 2L) and distinctly nodular ray parenchyma end walls (Figure 2M) are present in all genera of Pinaceae, although some species of Pinus do not conform (see Appendix B).

Indentures were also found in all genera, although they presented different degrees of development. In Abies (Figure 2N), they were well developed but in Cedrus, Keteleeria, Nothotsuga and Pinus, they were only slightly developed.

Lastly, cross-field pitting did not show a common pattern and cannot be used to establish groups, as variation in this feature is not only intergeneric but also intrageneric: Abies (piceoid, taxodioid), Cathaya (piceoid), Cedrus (piceoid, taxodioid), Keteleeria (cupressoid, taxodioid), Larix (piceoid), Nothotsuga (cupressoid, taxodioid), Picea (piceoid), Pinus (pinoid, window-like), Pseudolarix (piceoid), Pseudotsuga (piceoid) and Tsuga (piceoid).

\subsection{Axial Tracheids}

One of the most significant features of the axial tracheids of Pinaceae is the presence of helical thickenings: in Cathaya well developed in early and latewood; in some species of Larix only in latewood tracheids (L. decidua, L. griffithii, L. occidentalis); in Picea spinulosa well developed in early and latewood; in Picea abies, P. brachytyla, P. glauca, P. glehnii, P. jezoensis, P. koraiensis, P. mariana, P. sitchensis, P. torano only in latewood; in Pseudotsuga sinensis in early and latewood and in P. menziesii only in latewood (Figure 3A). The other genera of Pinaceae do not have helical thickenings in axial tracheids. Therefore, this can 
be used as a distinguishing feature to establish groups in Pinaceae, specific to Pinoideae (Cathaya-Larix-Picea-Pseudotsuga) with the exception of Pinus.

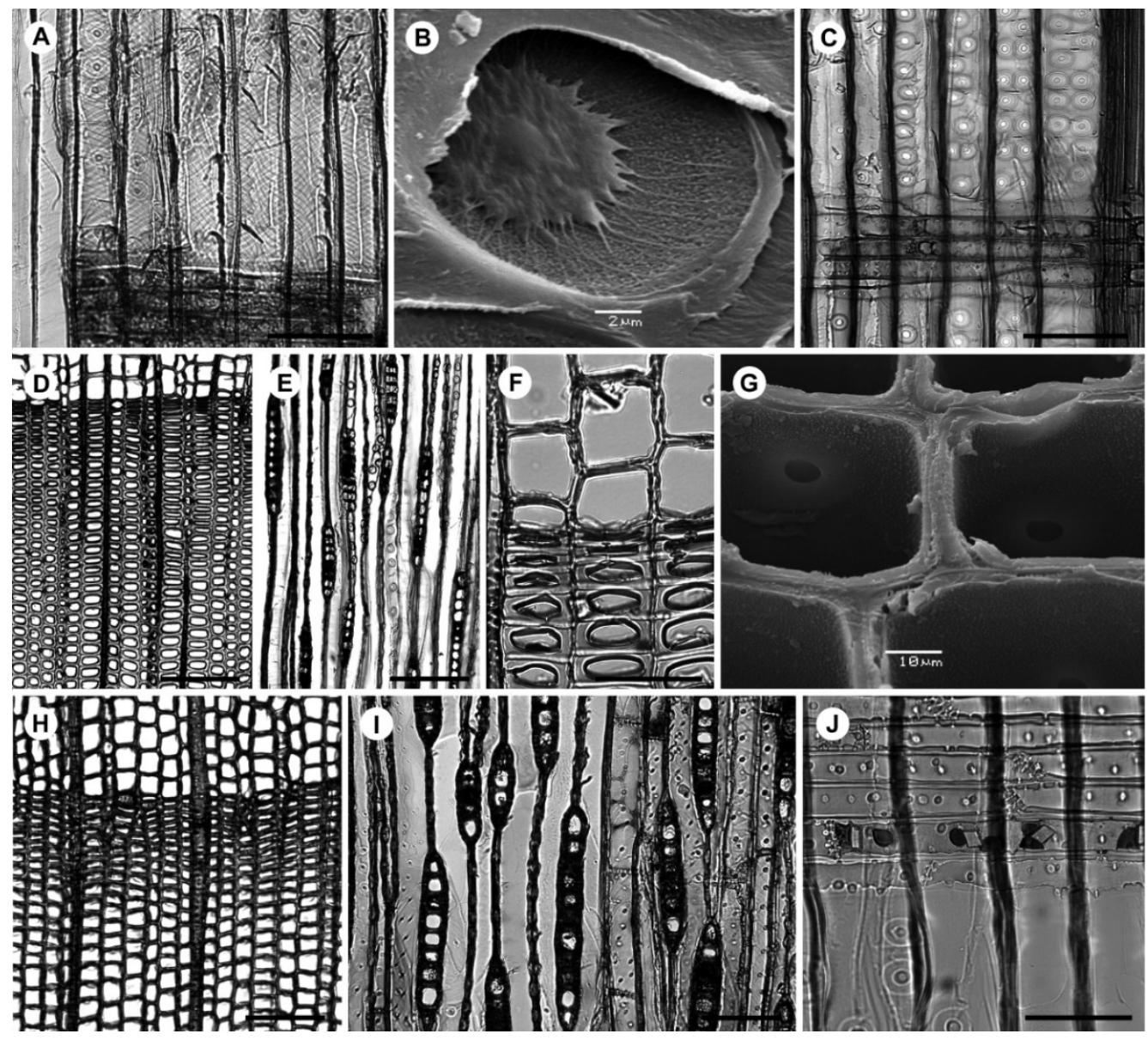

Figure 3. Axial tracheids, axial parenchyma and crystals. (A-G) Axial tracheids. (A) Helical thickenings Pseudotsuga sinensis. (B) SEM, scalloped tori Cedrus atlantica. (C) Biseriate tracheid pitting Larix occidentalis. (D) Organic deposits in tracheids Abies pinsapo. I Tracheid pitting in tangential walls Keteleeria evelyniana. (F) Tracheid pitting in tangential walls on the growth ring boundary Abies nordmanniana. (G) SEM, warty layer Abies pinsapo. (H-I) Axial parenchyma. (H) Marginal parenchyma Tsuga mertensiana. (I) Nodular transverse end wall Pseudolarix amabilis. (J) Crystals in ray parenchyma cells Abies procera. Scale bars: in $(\mathbf{B})=2 \mu \mathrm{m}$, in $(\mathbf{G})=10 \mu \mathrm{m}$, in $(\mathbf{F}, \mathbf{J})=50 \mu \mathrm{m}$, in $(\mathbf{A}, \mathbf{C})=100 \mu \mathrm{m}$, in $(\mathbf{D}, \mathbf{E}, \mathbf{H}, \mathbf{I})=150 \mu \mathrm{m}$.

Cedrus had scalloped tori (Figure 3B), a feature not observed in other Pinaceae, present in all samples studied [7,25]. Although Willebrand [31] described intermediate forms of scalloped tori in Pseudolarix, they were not found in the present study. Therefore, this feature does not support grouping of genera and, as with the presence of traumatic axial and radial resin canals, Cedrus seems to differ from the other genera.

When biseriate tracheid pitting was present in earlywood, it was in opposite arrangement in all genera (Figure 3C) and very rarely in alternate arrangement.

Organic deposits in tracheids were found only in A. pinsapo, agreeing with Esteban et al. [32], Abies guatemalensis and Pinus canariensis (Figure 3D), but should not be regarded as characteristic of the genus, as they are in Agathis and Araucaria [33,34]. Organic deposits in tracheids have also been cited in Picea sitchensis [10].

All the genera of Abietoideae studied presented tracheid pitting in tangential walls (Figure $3 \mathrm{E}$ ) in the vicinity of the growth ring, generally in the first rows of latewood (Figure 3F). Tracheid pitting was very scarce in the other genera. A warty layer was 
observed only in Abies, Cedrus, Nothotsuga and Tsuga (Figure 3G), although it has also been recorded in Pinus [25].

\subsection{Axial Parenchyma}

Although very scarce, axial parenchyma was observed in all genera of Pinaceae except Pinus. It was limited to the growth ring boundary, both in earlywood and latewood (Figure 3H). Transverse end walls were nodular in all genera studied (Figure 3I). The presence of this feature supports a single group for all genera except Pinus.

\subsection{Crystals}

The presence of crystals is a frequent feature in all genera of Abietoideae [35] and crystals also occur in some non-Abietoideae taxa. In this work, crystals were observed in many taxa of Abies (see Appendix B) and are a feature of this genus [18], all species of Cedrus and Keteleeria, Nothotsuga longibracteata, Pinus brutia, P. cembroides, P. contorta, P. halepensis, P. heldreichii, P. monophylla, Pseudolarix amabilis and all species of Tsuga except T. dumosa. They are usually located in marginal and submarginal rows of the ray parenchyma and in irregularly shaped marginal ray cells (Figure 3J).

The presence of crystals has even been used to differentiate very close species in Pinus [36,37]. Crystal inclusions have also been recorded in subsidiary tissue of resin canals, e.g., in Abies pinsapo [32]. In this study, they were observed only in traumatic resin canals of Abies.

These considerations indicate that the presence of crystals must be interpreted as a feature allowing the formation of a single group in Pinaceae.

\subsection{Anatomy and Phylogeny}

Irrespective of their typology and arrangement, resin canals allow a well-resolved group to be formed in Pinaceae as they occur in all genera, either normal and traumatic or only traumatic. Although some non-Pinaceae genera, specifically Cupressaceae, can have traumatic canals, their presence is occasional, as reported by Bailey and Faull [38] in Sequoia sempervirens, Jeffrey [39] in Sequoiadendron, Benkova and Schweingruber [40] in Microbiota and Esteban et al. [41] in Tetraclinis articulata.

The presence of ray tracheids also supports the grouping of the family Pinaceae. Although this feature is also found in non-Pinaceae conifers (Cupressus L., Sequoia Endl. and Thujopsis Siebold \& Zucc.) [7], it occurs in these species very rarely. However, the absence of ray tracheids in Keteleeria and their occasional presence in Abies and Pseudolarix weakens the group.

Other features such as pitted horizontal walls and nodular end walls in ray parenchyma cells, cross-field pitting and indentures do not support the grouping, as they occur in non-Pinaceae families. These considerations are supported by phylogeny studies by Gugerli et al. [42], who used the second intron in the mitochondrial gene nad1 to show that two clearly distinct clades can be established within the conifers: Pinaceae and nonPinaceae.

Based on wood anatomy, other subgroups can be established in the family Pinaceae that differ from the subfamilies proposed by Frankis [2] and Farjon [3] but agree with the classification by Lin et al. [5]. However, this classification differs from molecular phylogenetic studies by other authors.

Wang et al. [29] established the existence of two distinct clades within Pinaceae: Cathaya-Larix-Picea-Pinus-Pseudotsuga and Abies-Keteleeria-Nothotsuga-Pseudolarix-Tsuga. Gernandt et al. [22] confirmed this division by phylogenetic analysis of chloroplast DNA (matK and $r b c L$ ) and concluded that Pinaceae supports two clearly distinct monophyletic groups: Abietoideae and Pinoideae, corresponding with the general structure of the family in the two subfamilies.

Moreover, Wang et al. [29], in their study of intergeneric relations of Pinaceae using sequences of the chloroplast $m a t K$, mitochondrial nad5 and nuclear $4 C L$ genes, established a 
three-genome phylogeny consisting of the clade Larix-Picea-Pinus-Pseudotsuga similar to the phenogram established by Hart [43] based on cladistic analysis and to the clade established by Price et al. [44] through immunological comparison. The four genera of this clade have normal resin canals, both axial and radial, as does Cathaya.

Although some authors consider that the only species of the genus Cathaya (C. argyrophylla) belongs to the genus Pseudotsuga [45-47], using PCR-RFLP analysis of the chloroplast gene $\operatorname{trnK}$, concluded that Cathaya is a separate genus and must be treated outside of Pseudotsuga. The presence of axial and radial resin canals with thick-walled epithelial cells supports the clade Cathaya-Larix-Picea-Pseudotsuga, but excludes the genus Pinus, which has thin-walled epithelial cells.

Despite the obvious differences in the anatomy of the secondary xylem between Keteleeria and Nothotsuga and the other Abietoideae genera (presence of axial resin canals, arrangement of traumatic resin canals and absence of ray tracheids in Keteleeria), the two genera appear to form a well-resolved clade with Abies- Pseudolarix-Tsuga [47]. Liston et al. [21] also confirmed that Nothotsuga-Pseudolarix-Tsuga form a sister clade to AbiesKeteleeria, with only Cedrus remaining unresolved.

However, molecular evidence supports the genus Cedrus as a sister group to the other Pinaceae and reinforces the idea that it should occupy a basic or root position in the family, to the extent that the subfamily Abietoideae can be considered paraphyletic [22]. This coincides with the peculiar behaviour observed in two features of Cedrus: it is the only genus with scalloped tori and has traumatic radial resin canals even though it has no normal resin canals. These features, particularly the latter, constitute different behaviour in Cedrus from the clade Abies-Keteleeria-Nothotsuga-Pseudolarix-Tsuga, as these genera do not have tori or traumatic radial resin canals.

Despite these distinctive features of Cedrus, the genera in Abietoideae form a homogeneous group in terms of wood structure, except for the resin canals in Keteleeria and Nothotsuga and the absence of ray tracheids in Keteleeria, which supports the clade AbiesCedrus-Keteleeria-Nothotsuga-Pseudolarix-Tsuga, as all of these species have ray parenchyma with pitted horizontal walls and nodular end walls, indentures, scarce axial parenchyma on the growth ring boundary and crystals in ray parenchyma [35].

\section{Conclusions}

Wood anatomy and molecular phylogeny agree that Pinaceae is clearly differentiated from the other conifers by the presence of two features in its wood structure exclusive to the family-resin canals and ray tracheids-which are only very rarely present as exceptions in non-Pinaceae conifers.

Based on wood structure, Pinaceae clearly supports division into two groups: Pinoideae (Cathaya-Larix-Picea-Pinus-Pseudotsuga) and Abietoideae (Abies-Cedrus-Keteleeria-NothotsugaPseudolarix-Tsuga), although within Abietoideae two subgroups can be considered based on resin canals: with normal axial resin canals (Keteleeria-Nothotsuga) and without (AbiesCedrus-Pseudolarix-Tsuga).

Although division into two groups (Pinoideae and Abietoideae) is clearly supported by molecular phylogeny, the subgroups within Abietoideae differ from molecular phylogenetic studies that include Keteleeria and Nothotsuga with no exceptions and exclude Cedrus. However, the exclusion of Cedrus agrees with the differences in its wood structure compared to the anatomy of other genera.

Author Contributions: Conceptualization, L.G.E. and P.d.P.; Data curation, A.G.-I. and F.G.-F.; Formal analysis, A.G.-I. and F.G.-F.; Investigation, L.G.E., P.d.P., A.G.-I., F.G.-F., L.G.-E. and D.G.d.V.; Methodology, L.G.E., P.d.P., A.G.-I., F.G.-F., L.G.-E. and D.G.d.V.; Project administration, L.G.E. and P.d.P.; Resources, L.G.E., P.d.P., A.G.-I., F.G.-F., L.G.-E. and D.G.d.V.; Supervision, L.G.E.; Validation, L.G.E., P.d.P. and F.G.-F.; Visualization, L.G.E., P.d.P. and A.G.-I.; Writing-original draft, L.G.E. and P.d.P.; Writing—review and editing, L.G.E., P.d.P., A.G.-I., F.G.-F., L.G.-E. and D.G.d.V. All authors have read and agreed to the published version of the manuscript.

Funding: This research received no external funding. 
Data Availability Statement: Not Applicable.

Conflicts of Interest: The authors declare no conflict of interest.

\section{Appendix A}

List of the species, subspecies and varieties studied, with references to the collections from which the samples were obtained and list of the features observed. + Present, Absent, (+) Occasional. For wood sample acronyms see [23].

Abies alba Mill. (UPMAw-X1530); A. amabilis Douglas ex J.Forbes (UPMAw-X1216); A. balsamea (L.) Mill. (MADRw2173); A. borisii-regis Mattf. (MADw17846); A. bracteata (D. Don) Poit. (MADw18347); A. cephalonica Loudon (RBHw7079; MADRw1592; MADw1784); A. cilicica (Antoine \& Kotschy) Carrière (RBHw14036; MADRw2084; MADw17376; Uw362); A. concolor Lindl. ex Hildebr. (MADRw1577; MADRw1594); A. delavayi Franch. (KJw18361); A. durangensis Martínez (USw32800); A. firma Siebold \& Zucc. (CTFw11458ch); A. fraseri (Pursh) Poir. (RBHw5552; MADw771; USw14814); A. grandis (Douglas ex D.Don) Lindl. (UPMAw-X1526); A. guatemalensis Rehder (MADRw1593); A. hickelii Flous \& Gaussen (SJRw37237); A. holophylla Maxim. (UPMAw-X1155); A. homolepis Siebold \& Zucc. (MADw4428; TWTw1348; TWTw9276; TWTw11943; TWTw18725; USw23684); A. kawakamii (Hayata) T.Itô (RBHw 7243; MADw2006; USw21248); A. koreana E.H. Wilson (MADRw2171); A. lasiocarpa (Hook.) Nutt. (RBHw12097; RBHw11392; MADw25431; USw14492); A. lasiocarpa var. arizonica (Merriam) Lemmon (RBHw11383; MADRw1576); A. magnifica A.Murray bis (MADw6307; USw14485); A. mariesii Mast. (RBHw9103; RBHw7230; MADw20334; TWTw598; TWTw9347; TWTw18156; TWTw18691; TWTw20555; TWTw21799; USw24492); A. nephrolepis (Trautv. ex Maxim.) Maxim. (CTFw22366ch); A. nordmanniana (Steven) Spach (MADw10536; MADw39459; Uw314); A. nordmanniana Spach ssp. equi-trojani (Asch. \& Sint. ex Boiss.) Coode \& Cullen (RBHw14031; RBHw14034; MADw49056); A. numidica de Lannoy ex Carrière (K-Jw18393; Uw192); A. pindrow (Royle ex.D. Don) Royle (K-Jw18394); A. pinsapo Boiss. (UPMAw-X2175; UPMAw-X2176; UPMAw-X2177); A. pinsapo Boiss. var. tazaotana (S. Cózar ex Villar) Pourtet (UPMAw-X2267); A. pinsapo Boiss. var. marocana (Trab.) Ceballos \& Martín Bol. (UPMAw-X2268); A. procera Rehder (RBHw11428; MADw44891; USw19149); A. recurvata Mast. (SJRw23054-085); A. religiosa (Kunth) Schltdl. \& Cham. (CTFw1218); A. sachalinensis Mast. (CTFw11459ch); A. sibirica Ledeb. (K-Jw18406); A. spectabilis Spach (K-Jw18417); A. veitchii Lindl. (K-Jw18422); A. vejarii Martínez (MADw25208; USw32803); Cathaya argyrophylla Chun \& Kuang (UPMAw-X1732); Cedrus atlantica Manetti (K-Jw18423); C. brevifolia Elwes \& Henry (UPMAw-X0952); C. deodara (Roxb. ex Lambert) G. Don (K-Jw70743); C. libani A. Rich. (K-Jw18453); Keteleeria davidiana Beissn. (USw18469); K. evelyniana Mast. (MADw42042); K. fortunei Carrière (K-Jw18462); Larix decidua Mill. DC. (UPMAw-X0227; UPMAw-X0955); L. gmelini (Rupr.) Kuzen (UPMAwX1450; UPMAw-X1595); L. griffithii Hook. f. (K-Jw18509); L. laricina (Du Roi) K. Koch (UPMAw-X0955); L. kaempferi (Lamb.) Carriere (CTFw11460; CTFw19334); L. occidentalis Nutt. (UPMAw-X0956; UPMAw-X1223); L. sibirica Ledeb. (MADRw1732); Nothotsuga longibracteata (W.C. Cheng) H.H. Hu ex C.N. Page (MADw32679); Picea abies (L.) H. Karst. (UPMAw-X0957); P. alcoquiana (Veitch ex Lindl.) Carrière (K-Jw18566 W2); P. brachytyla (Franch.) E. Pritz. (UPMAw-X0958); P. glauca (Moench.) Voss. (UPMAwX0960; UPMAw-X1224); P. glehnii (F. Schmidt) Mast. (K-Jw18589); P. jezoensis (Siebold. \& Zucc.) Carrière (UPMAw-X0375); UPMAw-X1453); P. koraiensis Nakai (CTFw22363; CTFw26171); P. mariana (Mill.) Britton et al. (MADRw1590); P. omorika (Pancic) Purk. (UPMAw-X0119); P. rubens Sarg. (MADRw-P1588); P. sitchensis (Bong.) Carrière (UPMAwX0961); P. spinulosa (Griff.) Beissn. (K-Jw18642); P. torano (Siebold. Ex K. Koch) Koehne (UPMAw-P1264); Pinus arizonica Engelm. var. cooperi (C. E. Blanco) Farjon (UPMAwX1227); P. armandii Franch. (K-Jw18649); P. ayacahuite Ehrenb.ex Schltdl. (CTFw15135; CTFw15439; CTFw15129); P. banksiana Lamb. (UPMAw-X0962; UPMAw-X1521); P. brutia Ten. (UPMAw-P1272); P. canariensis C. Sm. (UPMAw-X2141); P. caribaea Morelet var. caribaea Barret \& Golfari (UPMAw-X2297); P. cembra L. (UPMAw-X0966; UPMAw- 
X1488); P. cembroides Zucc. (MADRw1574); P. contorta Douglas ex Loudon (UPMAwX0967; UPMAw-X1525); P. densiflora Siebold. \& Zucc. (UPMAw-X0376); P. devoniana Lindl. (UPMAw-X1230); P. douglasiana Martinez (UPMAw-P1279); P. elliottii Engelm. (UPMAw-X0968; UPMAw-X1517); P. gerardiana Wall ex D. Dom in Lambert (K-Jw18728); P. halepensis Mill. (UPMAw-X0970; UPMAw-X1563); P. hartwegii Lindl. (UPMAw-X1229); P. heldreichii D. H. Christ. (UPMAw-X2038); P. jeffreyi Balf. in Murray (MADRw1586); P. kesiya Royle ex Gordon (UPMAw-X0971; UPMAw-X1478); P. koraiensis Siebold. \& Zucc. (CTFw22356; CTFw26174; CTFw31572); P. lawsonii Roezl. ex Gordon (UPMAwX1228); P. leiophylla Schlecht \&Cham. (CTFw11323; CTFw25752; CTFw28882); P. massoniana Lambert (UPMAw-P1628); P. maximinoi H.E. Moore (UPMAw-X2292); P. merkusii Jungh \&de Vriese (K-Jw18762; CTFw3340; CTFw3353; CTFw7712); P. monophylla Torr. \& Frém. (UPMAw-X1730); P. montezumae Lamb. (CTFw11318; CTFw28949); P. morrisonicola Hayata (K-Jw18911); P. mugo Turra subsp. uncinata (Ramond ex DC.) Domin (UPMAw-X2338); P. nigra J. F. Arnold (UPMAw-X2298); P. palustris Mill. (UPMAw-X0973; UPMAw-X1476); P. parviflora Siebold. \& Zucc. (CTFw11464; CTFw19338; CTFw22357); P. peuce Griseb. (UPMAw-X0974; UPMAw-X1729); P. pinaster Aiton (UPMAw-P1302); P. pinea L. (UPMAw-X0973; UPMAw-X1476; UPMAw-X1787); P. ponderosa Douglas ex C. Lawson (UPMAw-X0976; UPMAw-X1232; UPMAw-X1480); P. pseudostrobus Lindl. (UPMAw-X2293); P. quadrifolia Parl. ex Sudw. (UPMAw-X1481); P. radiata D. Don (UPMAw-X0008; UPMAw-X0977; UPMAw-X1477); P. resinosa Aiton (UPMAw-X0978; UPMAw-X1233; UPMAw-X1482); P. rigida Mill. (UPMAw-X1483); P. strobus L. (UPMAwX0979; UPMAw-X1234; UPMAw-X1484); P. sylvestris L. (UPMAw-X2317); P. tabuliformis Carrière (CTFw28176); P. taeda L. (UPMAw-P1314); P. tecunumanii Eguiluz \& J. P. Perry (K-Jw18790); P. teocote Schiede \& Schlecht. (K-Jw18902); P. thunbergii Parl. (K-Jw18900); P. tropicalis Morelet (UPMAw-X2269); P. wallichiana A. B. Jacks. var. wallichiana (UPMAw-X0969; UPMAw-X1508); Pseudolarix amabilis Rehder (K-Jw18924); Pseudotsuga menziesii (Mirb.) Franco (UPMAw-X0983; UPMAw-X1518); P. sinensis Dode (KJw18940); P. menziesii (Mirb.) Franco var. menziesii (UPMAw-X0234; UPMAW-X0984; UPMAw-X1237); Tsuga canadensis Carrière (UPMAw-X1515); T. caroliniana Engelm. (K-Jw18950); T. chinensis (Franch.) Pritzel in Diels (CTFw26180 ch); T. diversifolia (Maxim.) Mast. (RBHw621; RBHw7081; RBHw9112; MADw48033; MADw26122; TWTw593; TWTw11949; TWTw18088; TWTw18152; TWTw18665; TWTw20551); T. dumosa Eichl. (K-Jw18953); T. heterophylla Sarg. (UPMAw-X1239); T. mertensiana (Bong.) Carrière (MADRw1397); T. sieboldii Carrière (KYOw0382). 


\section{Appendix B}

Table A1. Features observed in the species studied. + Present, - Absent, (+).

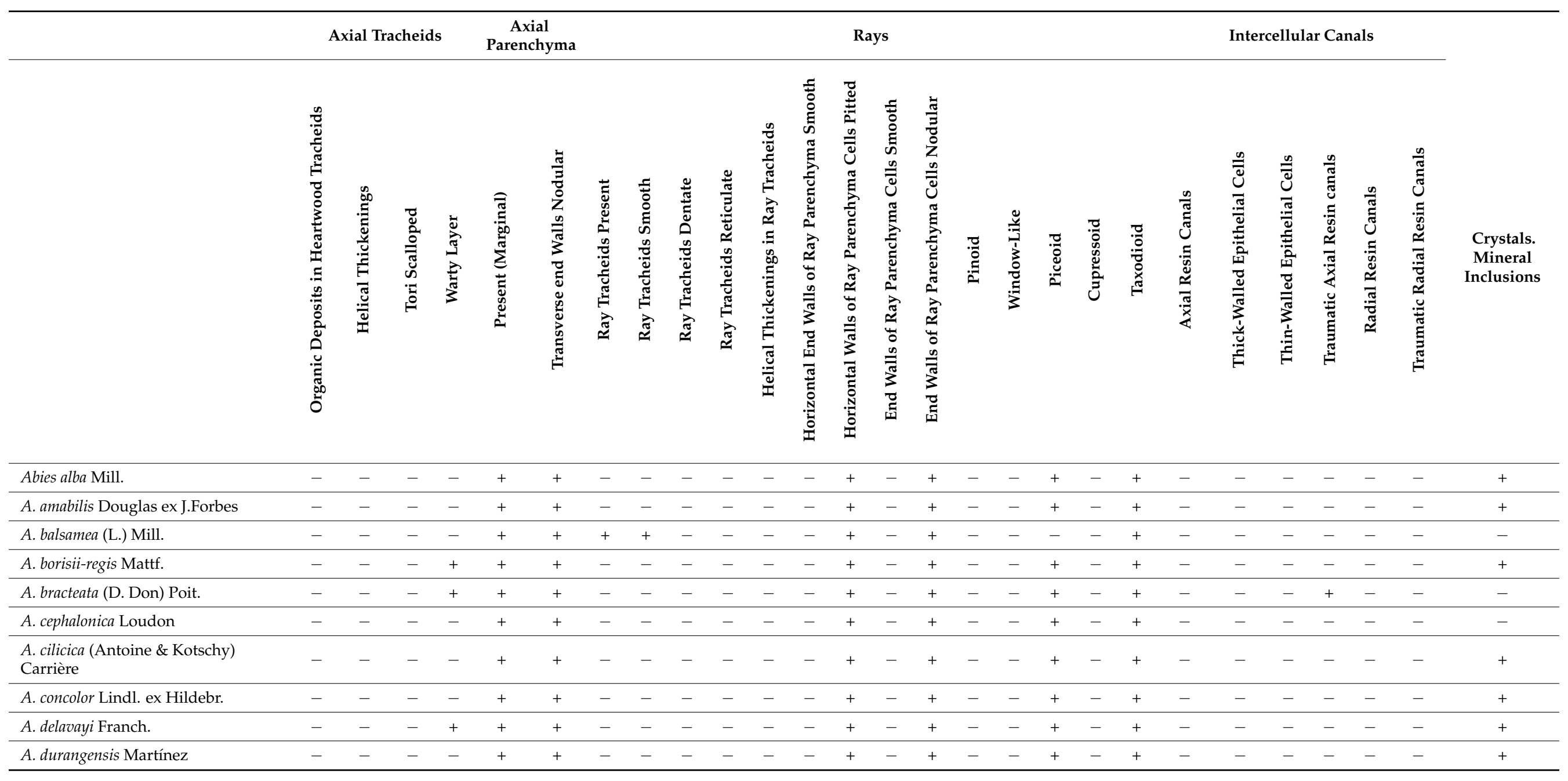


Table A1. Cont.

\begin{tabular}{|c|c|c|c|c|c|c|c|c|c|c|c|c|c|c|c|c|c|c|c|c|c|c|c|c|c|c|c|}
\hline A. firma Siebold \& Zucc. & - & - & - & + & + & + & - & - & - & - & - & - & + & - & + & - & - & - & - & + & - & - & - & - & - & - & + \\
\hline A. fraseri (Pursh) Poir. & - & - & - & + & + & + & - & - & - & - & - & - & + & - & + & - & - & - & - & + & - & - & - & - & - & - & + \\
\hline A. grandis (Douglas ex D.Don) Lindl. & - & - & - & - & + & + & - & - & - & - & - & - & + & - & + & - & - & - & - & + & - & - & - & - & - & - & - \\
\hline A. guatemalensis Rehder & + & - & - & - & + & + & - & - & - & - & - & - & + & - & + & - & - & - & - & + & - & - & - & + & - & - & + \\
\hline A. hickelii Flous \& Gaussen & - & - & - & - & + & + & - & - & - & - & - & - & + & - & + & - & - & - & - & + & - & - & - & - & - & - & - \\
\hline A. holophylla Maxim. & - & - & - & - & + & + & - & - & - & - & - & - & + & - & + & - & - & - & - & + & - & - & - & - & - & - & + \\
\hline A. homolepis Siebold \& Zucc. & - & - & - & - & + & + & - & - & - & - & - & - & + & - & + & - & - & - & - & + & - & - & - & - & - & - & + \\
\hline A. koreana E.H.Wilson & - & - & - & - & + & + & - & - & - & - & - & - & + & - & + & - & - & - & - & + & - & - & - & - & - & - & - \\
\hline A. lasiocarpa (Hook.) Nutt. & - & - & - & - & + & + & - & - & - & - & - & - & + & - & + & - & - & - & - & + & - & - & - & - & - & - & + \\
\hline $\begin{array}{l}\text { A. lasiocarpa var. arizonica (Merriam) } \\
\text { Lemmon }\end{array}$ & - & - & - & - & + & + & - & - & - & - & - & - & + & - & + & - & - & - & - & + & - & - & - & - & - & - & - \\
\hline A. magnifica A.Murray bis & - & - & - & - & + & + & - & - & - & - & - & - & + & - & + & - & - & - & - & + & - & - & - & - & - & - & + \\
\hline A. mariesii Mast. & - & - & - & - & + & + & - & - & - & - & - & - & + & - & + & - & - & - & - & + & - & - & - & - & - & - & + \\
\hline $\begin{array}{l}\text { A. nephrolepis (Trautv. ex Maxim.) } \\
\text { Maxim. }\end{array}$ & - & - & - & - & + & + & - & - & - & - & - & - & + & - & + & - & - & - & - & + & - & - & - & + & - & - & - \\
\hline $\begin{array}{l}\text { A. nordmanniana Spach ssp. } \\
\text { equi-trojani (Asch. \& Sint. ex Boiss.) }\end{array}$ & - & - & - & - & + & + & - & - & - & - & - & - & + & - & + & - & - & - & - & + & - & - & - & - & - & - & + \\
\hline A. numidica de Lannoy ex Carrière & - & - & - & - & + & + & - & - & - & - & - & - & + & - & + & - & - & - & - & + & - & - & - & - & - & - & + \\
\hline A. pindrow (Royle ex.D. Don) Royle & - & - & - & - & + & + & - & - & - & - & - & - & + & - & + & - & - & - & - & + & - & - & - & - & - & - & + \\
\hline A. pinsapo Boiss. & + & - & - & - & + & + & - & - & - & - & - & - & + & - & + & - & - & - & - & + & - & - & - & - & - & - & + \\
\hline $\begin{array}{l}\text { A. pinsapo Boiss. var. tazaotana } \\
\text { (S.Cózar ex Villar) Pourtet }\end{array}$ & - & - & - & - & + & + & - & - & - & - & - & - & + & - & + & - & - & - & - & + & - & - & - & - & - & - & + \\
\hline $\begin{array}{l}\text { A. pinsapo Boiss. var. marocana (Trab.) } \\
\text { Ceballos \& Martín Bol. }\end{array}$ & - & - & - & - & + & + & - & - & - & - & - & - & + & - & + & - & - & - & - & + & - & - & - & - & - & - & + \\
\hline A. procera Rehder & - & - & - & - & + & + & - & - & - & - & - & - & + & - & + & - & - & - & - & + & - & - & - & - & - & - & + \\
\hline A. recurvata Mast. & - & - & - & - & + & + & - & - & - & - & - & - & + & - & + & - & - & - & - & + & - & - & - & - & - & - & - \\
\hline
\end{tabular}




\section{Table A1. Cont.}

\begin{tabular}{|c|c|c|c|c|c|c|c|c|c|c|c|c|c|c|c|c|c|c|c|c|c|c|c|c|c|c|c|}
\hline A. religiosa (Kunth) Schltdl. \& Cham. & - & - & - & - & + & + & - & - & - & - & - & - & + & - & + & - & - & - & - & + & - & - & - & - & - & - & + \\
\hline A. sachalinensis Mast. & - & - & - & - & + & + & - & - & - & - & - & - & + & - & + & - & - & - & - & + & - & - & - & - & - & - & - \\
\hline A. sibirica Ledeb. & - & - & - & - & + & + & - & - & - & - & - & - & + & - & + & - & - & - & - & + & - & - & - & - & - & - & - \\
\hline A. spectabilis Spach & - & - & - & + & + & + & - & - & - & - & - & - & + & - & + & - & - & - & - & + & - & - & - & - & - & - & - \\
\hline A. veitchii Lindl. & - & - & - & - & + & + & - & - & - & - & - & - & + & - & + & - & - & - & - & + & - & - & - & + & - & - & - \\
\hline A. vejarii Martínez & - & - & - & - & + & + & - & - & - & - & - & - & + & - & + & - & - & - & - & + & - & - & - & - & - & - & - \\
\hline Cathaya argyrophylla Chun \& Kuang & - & + & - & - & + & + & + & + & - & - & + & - & + & - & + & - & - & + & - & - & + & + & - & + & + & + & - \\
\hline Cedrus atlantica Manetti & - & - & + & + & + & + & + & + & - & - & - & - & + & - & + & - & - & + & - & + & - & - & - & - & - & - & + \\
\hline C. brevifolia Elwes \& Henry & - & - & + & + & + & + & + & + & - & - & - & - & + & - & + & - & - & + & - & + & - & - & - & + & - & + & + \\
\hline C. deodara (Roxb. ex Lambert) G.Don & - & - & + & + & + & + & + & + & - & - & - & - & + & - & + & - & - & + & - & + & - & - & - & - & - & - & + \\
\hline C. libani A.Rich. & - & - & + & + & + & + & + & + & - & - & - & - & + & - & + & - & - & + & - & + & - & - & - & - & - & - & + \\
\hline Keteleeria davidiana Beissn. & - & - & - & - & + & + & - & - & - & - & - & - & + & - & + & - & - & - & + & - & + & + & - & - & - & - & + \\
\hline K. evelyniana Mast. & - & - & - & - & + & + & - & - & - & - & - & - & + & - & + & - & - & - & - & + & + & + & - & - & - & - & + \\
\hline K. fortunei Carrière & - & - & - & - & + & + & - & - & - & - & - & - & + & - & + & - & - & - & + & + & + & + & - & + & - & - & + \\
\hline Larix decidua Mill. DC. & - & +1 & - & - & + & + & + & + & - & - & - & - & + & - & + & - & - & + & - & - & + & + & - & + & + & + & - \\
\hline L. griffithii Hook. f. & - & +1 & - & - & - & - & + & + & - & - & - & - & + & - & + & - & - & + & - & - & + & + & - & - & + & - & - \\
\hline L. laricina (Du Roi) K. Koch & - & - & - & - & - & - & + & + & - & - & - & - & + & - & + & - & - & + & - & - & + & + & - & - & + & - & - \\
\hline L. kaempferi (Lamb.) Carriere & - & - & - & - & - & - & + & + & - & - & - & - & + & - & + & - & - & + & - & - & + & + & - & - & + & - & - \\
\hline L. occidentalis Nutt. & - & +1 & - & - & + & + & + & + & - & - & - & - & + & - & + & - & - & + & - & - & + & + & - & + & + & + & - \\
\hline L. sibirica Ledeb. & - & - & - & - & - & - & + & + & - & - & - & - & + & - & + & - & - & + & - & - & + & + & - & - & + & - & - \\
\hline $\begin{array}{l}\text { Nothotsuga longibracteata (W.C.Cheng) } \\
\text { H.H.Hu ex C.N.Page }\end{array}$ & - & - & - & + & + & + & + & + & - & - & - & - & + & - & + & - & - & - & + & + & $+{ }^{2}$ & $+{ }^{2}$ & - & - & - & $+{ }^{3}$ & + \\
\hline Picea abies (L.) H. Karst. & - & +1 & - & - & - & - & + & + & - & - & - & - & + & - & + & - & - & + & - & - & + & + & - & + & + & + & - \\
\hline $\begin{array}{l}\text { P. alcoquiana (Veitch ex Lindl.) } \\
\text { Carrière }\end{array}$ & - & - & - & - & - & - & + & + & - & - & - & - & + & - & + & - & - & + & - & - & + & + & - & - & + & - & - \\
\hline P. brachytyla (Franch.) E. Pritz. & - & +1 & - & - & - & - & + & + & - & - & - & - & + & - & + & - & - & + & - & - & + & + & - & - & + & - & - \\
\hline P. glauca (Moench.) Voss. & - & +1 & - & - & - & - & + & + & - & - & - & - & + & - & + & - & - & + & - & - & + & + & - & - & + & - & - \\
\hline
\end{tabular}




\section{Table A1. Cont.}

\begin{tabular}{|c|c|c|c|c|c|c|c|c|c|c|c|c|c|c|c|c|c|c|c|c|c|c|c|c|c|c|c|}
\hline P. glehnii (F. Schmidt) Mast. & - & +1 & - & - & + & + & + & + & - & - & - & - & + & - & + & - & - & + & - & - & + & + & - & - & + & - & - \\
\hline P. jezoensis (Siebold. \& Zucc.) Carrière & - & $+{ }^{1}$ & - & - & - & - & + & + & - & - & - & - & + & - & + & - & - & + & - & - & + & + & - & - & + & - & - \\
\hline P. koraiensis Nakai & - & +1 & - & - & - & - & + & + & - & - & - & - & + & - & + & - & - & + & - & - & + & + & - & - & + & - & - \\
\hline P. mariana (Mill.) Britton et al. & - & +1 & - & - & - & - & + & + & - & - & - & - & + & - & + & - & - & + & - & - & + & + & - & - & + & - & - \\
\hline P. omorika (Pancic) Purk. & - & - & - & - & - & - & + & + & - & - & - & - & + & - & + & - & - & + & - & - & + & + & - & - & + & - & - \\
\hline P. rubens Sarg. & - & - & - & - & - & - & + & + & - & - & - & - & + & - & + & - & - & + & - & - & + & + & - & - & + & - & - \\
\hline P. sitchensis (Bong.) Carrière & - & +1 & - & - & - & - & + & + & - & - & - & - & + & - & + & - & - & + & - & - & + & + & - & - & + & - & - \\
\hline $\begin{array}{l}\text { P. torano (Siebold. Ex K. Koch) } \\
\text { Koehne }\end{array}$ & - & $+{ }^{1}$ & - & - & - & - & + & + & - & - & + & - & + & - & + & - & - & + & - & - & + & + & - & - & + & - & - \\
\hline $\begin{array}{l}\text { Pinus arizonica Engelm. var. cooperi } \\
\text { (C. E. Blanco) Farjon }\end{array}$ & - & - & - & - & - & - & + & - & + & + & - & + & - & + & - & + & - & - & - & - & + & - & + & + & + & + & - \\
\hline P. armandii Franch. & - & - & - & - & - & - & + & + & - & - & - & - & + & + & + & - & + & - & - & - & + & - & + & - & + & - & - \\
\hline P. ayacahuite Ehrenb.ex Schltdl. & - & - & - & - & - & - & + & + & - & - & - & + & - & + & + & - & + & - & - & - & + & - & + & - & + & - & - \\
\hline P. banksiana Lamb. & - & - & - & - & - & - & + & - & + & + & - & + & - & + & - & + & - & - & - & - & + & - & + & - & + & - & - \\
\hline P. brutia Ten. & - & - & - & - & - & - & + & + & + & - & - & - & + & - & + & + & - & - & - & - & + & - & + & - & + & - & + \\
\hline $\begin{array}{l}\text { P. caribaea Morelet var. caribaea Barret } \\
\text { \& Golfari }\end{array}$ & - & - & - & - & - & - & + & - & + & + & - & + & - & + & - & + & - & - & - & - & + & - & + & - & + & - & - \\
\hline P. cembra L. & - & - & - & - & - & - & + & + & - & - & - & + & - & + & - & - & + & - & - & - & + & - & + & - & + & - & - \\
\hline P. cembroides Zucc. & - & - & - & - & - & - & + & + & - & - & - & + & - & + & - & + & - & - & - & - & + & - & + & - & + & - & + \\
\hline P. contorta Douglas ex Loudon & - & - & - & - & - & - & + & - & + & + & - & + & - & + & + & + & - & - & - & - & + & - & + & - & + & - & + \\
\hline P. densiflora Siebold. \& Zucc. & - & - & - & - & - & - & + & - & + & - & - & + & - & + & - & - & + & - & - & - & + & - & + & - & + & - & - \\
\hline P. devoniana Lindl. & - & - & - & - & - & - & + & - & + & + & - & + & - & + & + & + & - & - & - & - & + & - & + & - & + & - & - \\
\hline P. douglasiana Martinez & - & - & - & - & - & - & + & - & + & + & - & + & - & + & + & + & - & - & - & - & + & - & + & - & + & - & - \\
\hline P. elliottii Engelm. & - & - & - & - & - & - & + & - & + & + & - & + & - & + & - & + & - & - & - & - & + & - & + & - & + & - & - \\
\hline $\begin{array}{l}\text { P. gerardiana Wall ex D.Dom in } \\
\text { Lambert }\end{array}$ & - & - & - & - & - & - & + & + & + & - & - & - & + & - & + & + & - & - & - & - & + & - & + & - & + & - & + \\
\hline
\end{tabular}


Table A1. Cont.

\begin{tabular}{|c|c|c|c|c|c|c|c|c|c|c|c|c|c|c|c|c|c|c|c|c|c|c|c|c|c|c|c|}
\hline P. griffithii McClell & - & - & - & - & - & - & + & + & + & - & - & + & - & + & + & + & - & - & - & - & + & - & + & - & + & - & - \\
\hline P. halepensis Mill. & - & - & - & - & - & - & + & + & + & - & - & + & - & + & + & + & - & - & - & - & + & - & + & + & + & + & + \\
\hline P. hartwegii Lindl. & - & - & - & - & - & - & + & + & + & - & - & + & - & + & + & + & - & - & - & - & + & - & + & - & + & - & - \\
\hline P. heldreichii D. H. Christ. & - & - & - & - & - & - & + & - & + & + & - & + & - & + & + & + & - & - & - & - & + & - & + & - & + & - & + \\
\hline P. jeffreyi Balf. in Murray & - & - & - & - & - & - & + & - & + & + & - & + & - & + & - & + & - & - & - & - & + & - & + & - & + & - & - \\
\hline P. kesiya Royle ex Gordon & - & - & - & - & - & - & + & - & + & - & - & + & - & + & - & - & + & - & - & - & + & - & + & - & + & - & - \\
\hline P. koraiensis Siebold. \& Zucc. & - & - & - & - & - & - & + & + & - & - & - & + & - & + & - & - & + & - & - & - & + & - & + & - & + & - & - \\
\hline P. leiophylla Schlecht \& Cham. & - & - & - & - & - & - & + & - & + & - & - & + & - & + & - & + & - & - & - & - & + & - & + & - & + & - & - \\
\hline P. massoniana Lambert & - & - & - & - & - & - & + & - & + & - & - & + & - & + & - & - & + & - & - & - & + & - & + & - & + & - & - \\
\hline P. maximinoi H.E. Moore & - & - & - & - & - & - & + & - & + & + & - & + & - & + & - & + & - & - & - & - & + & - & + & - & + & - & - \\
\hline P. merkusii Jungh \& de Vriese & - & - & - & - & - & - & + & + & + & - & - & + & - & + & - & + & - & - & - & - & + & - & + & - & + & - & - \\
\hline P. monophylla Torr. \& Frém. & - & - & - & - & - & - & + & + & + & - & - & - & + & - & + & + & - & - & - & - & + & - & + & - & + & - & + \\
\hline P. montezumae Lamb. & - & - & - & - & - & - & + & - & + & - & - & + & - & + & + & + & - & - & - & - & + & - & + & - & + & - & - \\
\hline P. morrisonicola Hayata & - & - & - & - & - & - & + & + & - & - & - & + & - & + & + & - & + & - & - & - & + & - & + & - & + & - & - \\
\hline P. nigra J. F. Arnold & - & - & - & - & - & - & + & - & + & - & - & + & - & + & - & - & + & - & - & - & + & - & + & + & + & + & - \\
\hline P. palustris Mill. & - & - & - & - & - & - & + & - & + & + & - & + & - & + & + & + & - & - & - & - & + & - & + & - & + & - & - \\
\hline P. parviflora Siebold. \& Zucc. & - & - & - & - & - & - & + & + & - & - & - & + & - & + & - & - & + & - & - & - & + & - & + & - & + & - & - \\
\hline P. peuce Griseb. & - & - & - & - & - & - & + & + & - & - & - & + & - & + & + & - & + & - & - & - & + & - & + & - & + & - & - \\
\hline P. pinaster Aiton & - & - & - & - & - & - & + & - & + & - & - & + & - & + & + & + & - & - & - & - & + & - & + & + & + & + & - \\
\hline P. pinea $\mathrm{L}$. & - & - & - & - & - & - & + & + & + & - & - & - & + & - & + & + & - & - & - & - & + & - & + & - & + & - & - \\
\hline P. ponderosa Douglas ex C. Lawson & - & - & - & - & - & - & + & - & + & + & - & + & - & + & + & + & - & - & - & - & + & - & + & - & + & - & - \\
\hline P. pseudostrobus Lindl. & - & - & - & - & - & - & + & - & + & - & - & + & - & + & - & + & - & - & - & - & + & - & + & - & + & - & - \\
\hline P. quadrifolia Parl. ex Sudw. & - & - & - & - & - & - & + & + & + & - & - & - & + & - & + & + & - & - & - & - & + & - & + & - & + & - & - \\
\hline P. radiata D. Don & - & - & - & - & - & - & + & - & + & - & - & + & - & - & + & + & - & - & - & - & + & - & + & - & + & - & - \\
\hline P. resinosa Aiton & - & - & - & - & - & - & + & - & + & - & - & + & - & + & - & - & + & - & - & - & + & - & + & - & + & - & - \\
\hline P. rigida Mill. & - & - & - & - & - & - & + & - & + & + & - & + & - & + & + & + & - & - & - & - & + & - & + & - & + & - & - \\
\hline
\end{tabular}


Table A1. Cont.

\begin{tabular}{|c|c|c|c|c|c|c|c|c|c|c|c|c|c|c|c|c|c|c|c|c|c|c|c|c|c|c|c|}
\hline P. strobus L. & - & - & - & - & - & - & + & + & - & - & - & + & - & + & - & - & + & - & - & - & + & - & + & - & + & - & - \\
\hline P. sylvestris $\mathrm{L}$. & - & - & - & - & - & - & + & - & + & - & - & + & - & + & - & - & + & - & - & - & + & - & + & - & + & - & - \\
\hline P. tabuliformis Carrière & - & - & - & - & - & - & + & - & + & - & - & + & - & + & - & - & + & - & - & - & + & - & + & - & + & - & - \\
\hline P. taeda L. & - & - & - & - & - & - & + & - & + & + & - & + & - & + & + & + & - & - & - & - & + & - & + & - & + & - & - \\
\hline P. tecunumanii Eguiluz \& J. P. Perry & - & - & - & - & - & - & + & - & + & + & - & + & - & + & + & + & - & - & - & - & + & - & + & - & + & - & - \\
\hline P. teocote Schiede \& Schlecht. & - & - & - & - & - & - & + & - & + & - & - & + & - & + & + & + & - & - & - & - & + & - & + & - & + & - & - \\
\hline P. thunbergii Parl. & - & - & - & - & - & - & + & - & + & - & - & + & - & + & - & - & + & - & - & - & + & - & + & - & + & - & - \\
\hline P. tropicalis Morelet & - & - & - & - & - & - & + & - & + & - & - & + & - & + & - & - & + & - & - & - & + & - & + & - & + & - & - \\
\hline $\begin{array}{l}\text { P. wallichiana A. B. Jacks. var. } \\
\text { wallichiana }\end{array}$ & - & - & - & - & - & - & + & + & - & - & - & + & - & + & - & - & + & - & - & - & + & - & + & - & + & - & - \\
\hline Pseudolarix amabilis Rehder & - & - & - & - & + & + & + & + & - & - & - & - & + & - & + & - & - & + & - & - & - & - & - & - & - & $+{ }^{3}$ & + \\
\hline Pseudotsuga menziesii (Mirb.) Franco & - & +1 & - & - & + & + & + & + & - & - & - & - & + & - & + & - & - & + & - & - & + & + & - & + & + & + & - \\
\hline $\begin{array}{l}\text { P. menziesii (Mirb.) Franco var. } \\
\text { menziesii }\end{array}$ & - & + & - & - & + & + & + & + & - & - & - & - & + & - & + & - & - & + & - & - & + & + & - & - & + & - & - \\
\hline P. sinensis Dode & - & + & - & - & + & + & + & + & - & - & + & - & + & - & + & - & - & + & - & - & + & + & - & - & + & - & - \\
\hline Tsuga canadensis Carrière & - & - & - & + & + & + & + & + & - & - & - & - & + & - & + & - & - & + & - & - & - & - & - & + & - & - & + \\
\hline T. caroliniana Engelm. & - & - & - & + & + & + & + & + & - & - & - & - & + & - & + & - & - & + & - & - & - & - & - & - & - & - & + \\
\hline T. chinensis (Franch.) Pritzel in Diels & - & - & - & + & + & + & + & + & - & - & - & - & + & - & + & - & - & + & - & - & - & - & - & - & - & - & + \\
\hline T. diversifolia (Maxim.) Mast. & - & - & - & + & + & + & + & + & - & - & - & - & + & - & + & - & - & + & - & - & - & - & - & - & - & - & + \\
\hline T. dumosa Eichl. & - & - & - & + & + & + & + & + & - & - & - & - & + & - & + & - & - & + & - & - & - & - & - & - & - & - & - \\
\hline T. heterophylla Sarg. & - & - & - & + & + & + & + & + & - & - & - & - & + & - & + & - & - & + & - & - & - & - & - & - & - & - & + \\
\hline T. mertensiana (Bong.) Carrière & - & - & - & + & + & + & + & + & - & - & - & - & + & - & + & - & - & + & - & - & - & - & - & - & - & - & + \\
\hline T. sieboldii Carrière & - & - & - & + & + & + & + & + & - & - & - & - & + & - & + & - & - & + & - & - & - & - & - & - & - & - & + \\
\hline
\end{tabular}




\section{References}

1. POWO. Plants of the World Online. Facilitated by the Royal Botanic Gardens, Kew. Available online: http://www. plantsoftheworldonline.org/ (accessed on 14 July 2021).

2. Frankis, M.P. Generic inter-relationships in Pinaceae. Notes R. Bot. Gard. Edinb. 1989, 45, 527-548.

3. Farjon, A. Pinaceae: Drawings and Descriptions of the Genera Abies, Cedrus, Pseudolarix, Keteleeria, Nothotsuga, Tsuga, Cathaya, Pseudotsuga, Larix and Picea; Koeltz Scientific Books: Königstein, Germany, 1900; p. 330.

4. Wu, H.; Hu, Z.H. Comparative anatomy of resin ducts of the Pinaceae. Trees Struct. Funct. 1997, 11, 135-143. [CrossRef]

5. Lin, J.X.; Liang, E.Y.; Farjon, A. The occurrence of vertical resin canals in Keteleeria, with reference to its systematic position in Pinaceae. Bot. J. Linn. Soc. 2000, 134, 567-574. [CrossRef]

6. Bailey, I.W. Anatomical characters in the evolution of Pinus. Am. Nat. 1910, 44, 284-293. [CrossRef]

7. Phillips, E.W.J. Identification of Softwoods by their Microscopic Structure; Forest Products Research Bulletin No. 22; HMSO: London, UK, 1948; p. 55.

8. Greguss, P. Identification of Living Gymnosperms on the Basis of Xylotomy; Akadémiai Kiadó: Budapest, Hungary, $1955 ;$ p. 263.

9. Jacquiot, C. Atlas D'anatomie des Bois des Conifères; Institut National du Bois: Paris, France, 1955; p. 134.

10. Kukachka, B.F. Identification of coniferous woods. Tappi 1960, 43, 887-896.

11. Jin-Xing, L.; Yu-Shi, H.; Wang, F.H. Wood and Bark Anatomy of Nothotsuga (Pinaceae). Ann. Mo. Bot. Gard. 1995, 82, 603-609. [CrossRef]

12. Esteban, L.G.; de Palacios, P.; Guindeo, A.; García, L.; Lázaro, I.; González, L.; Rodríguez, Y.; García, F.; Bobadilla, I.; Camacho, A. Anatomy and Identification of Conifers Wood as a Species; Fundación Conde del Valle de Salazar-Mundi Prensa: Madrid, Spain, 2002; p. 421.

13. Esteban, L.G.; de Palacios, P.; García Fernández, F.; Martín, J.A. Wood anatomical relationships within Abies spp. from the Mediterranean area: A phyletic approach. Investig. Agrar. Sist. Recur. For. 2009, 18, 213-225. [CrossRef]

14. Esteban, L.G.; de Palacios, P.; García Fernández, F.; Moreno, R. Wood anatomy of the genus Abies: A review. IAWA J. 2009, 30, 231-245. [CrossRef]

15. Heinz, I. Systematische Erfassung und Dokumentation der Mikroanatomischen Merkmale der Nadelhölzer aus der Klasse der Pinatae; Technische Universität München: Munich, Germany, 2004; p. 209.

16. Bannan, M.W. Vertical resin ducts in the secondary wood of the Abietineae. New Phytol. 1936, 35, 11-46. [CrossRef]

17. Xie, F.H. Wood Structure and Taxonomical Position of Cathaya (Abstract). Symposium on the Exploitation of Tropical Resources in South China; Forestry Press: Beijing, China, 1957.

18. Kennedy, R.W.; Sastry, C.B.R.; Barton, G.M.; Ellis, E.L. Crystals in wood of genus Abies indigenous to Canada and United States. Can. J. Bot. 1968, 46, 1221-1228. [CrossRef]

19. Jain, K.K. Evolution of wood structure in Pinaceae. Isr. J. Bot. 1976, 25, 28-33.

20. Fahn, A. Secretory Tissues in Plants; Academic Press: London, UK, 1979; p. 302.

21. Liston, A.; Gernandt, D.S.; Vining, T.F.; Campbell, C.S.; Piñero, D. Molecular phylogeny of Pinaceae and Pinus. Acta Hortic. 2003, 615, 107-114. [CrossRef]

22. Gernandt, D.S.; Magallón, S.; López, G.G.; Flores, O.Z.; Willyard, A.; Liston, A. Use of simultaneous analyses to guide fossil-based calibrations of Pinaceae phylogeny. Int. J. Plant Sci. 2008, 169, 1086-1099. [CrossRef]

23. Lynch, A.H.; Gasson, P.; Lens, F. Index Xylariorum 4.1. Institutional Wood Collections of the World. IAWA J. 2016. Available online: https:/ / www.iawa-website.org/uploads/soft/Abstracts/Index\%20Xylariorum\%204.1.pdf (accessed on 14 July 2021).

24. Jane, F.W. The Structure of Wood, 2nd ed.; Adam \& Charles Black: London, UK, 1970; p. 478.

25. Richter, H.G.; Grosser, D.; Heinz, I.; Gasson, P.E. IAWA COMMITTEE. IAWA List of microscopic features for softwood identification. IAWA J. 2004, 25, 1-70. [CrossRef]

26. Holden, R. Ray tracheids in the Coniferales. Bot. Gaz. 1913, 55, 56-65. [CrossRef]

27. Hudson, R.H. The anatomy of the genus Pinus in relation to its classification. J. Inst. Wood Sci. 1960, 6, $26-46$.

28. Chamberlain, C.J. Gymnosperms. Structure and Evolution; University of Chicago Press: Chicago, IL, USA, 1935 ; p. 484.

29. Wang, X.Q.; Tank, D.C.; Sang, T. Phylogeny and divergence times in Pinaceae: Evidence from three genomes. Mol. Biol. Evol. 2000, 17, 773-781. [CrossRef]

30. Chrysler, M.A. The medullary ray of Cedrus. Bot. Gaz. 1915, 59, 387-396. [CrossRef]

31. Willebrand, G. Untersuchung von ausgewählten mikroanatomische Merkmalen zur Bestimmung von Nadelhölzern. Ph.D. Thesis, Fachhochschule Rosenheim, Rosenheim, Germany, 1995.

32. Esteban, L.G.; de Palacios, P. Guindeo, A.; Fernandez, F.G. Comparative anatomy of the wood of Abies pinsapo and its two Moroccan varieties. IAWA J. 2007, 28, 285-299. [CrossRef]

33. Esteban, L.G.; Guindeo, A.; de Palacios, P. Maderas de Coníferas. Anatomía de Géneros; Fundación Conde del Valle de Salazar: Madrid, Spain, 1996; p. 336.

34. Esteban, L.G.; Gasson, P.; Climent, J.M.; de Palacios, P.; Guindeo, A. The wood of Pinus canariensis and its resinous heartwood. IAWA J 2005, 26, 69-77. [CrossRef] 
35. Esteban, L.G.; de Palacios, P. Comparative wood anatomy in Abietoideae (Pinaceae). Bot. J. Linn. Soc. 2009, 160, 184-196. [CrossRef]

36. Kellogg, R.M.; Rowe, S.; Koeppen, R.C.; Miller, R.B. Identification of the wood of the soft pines of Western North-America. IAWA Bull. 1982, 3, 95-101. [CrossRef]

37. Wiedenhoeft, A.C.; Miller, R.B.; Theim, T.J. Analysis of three microscopic characters for separating the wood of Pinus contorta and P. ponderosa. IAWA J. 2003, 24, 257-267. [CrossRef]

38. Bailey, I.W.; Faull, A.F. The cambium and its derivative tissues. IX. Structural variability in the redwood, Sequoia sempervirens, and its significance in the identification of fossil woods. J. Arnold Arbor. 1934, 15, 233-254. [CrossRef]

39. Jeffrey, E.C. The comparative anatomy and phylogeny of the Coniferales. Part 1. The genus Sequoia. Mem. Boston Soc. Nat. Hist. 1903, 5, 441-459.

40. Benkova, V.E.; Schweingruber, F.H. Anatomy of Russian Woods. An Atlas for the Identification of Trees, Shrubs, Dwarf Shrubs and Woody Lianas from Russia; Haupt Verlag: Bern, Switzerland, 2004; p. 456.

41. Esteban, L.G.; de Palacios, P.; García-Iruela, A.; Román-Jordán, E.; García-Fernández, F.; Díaz Fernández, S.; Conde, M. Wood anatomy of Tetraclinis articulata from its natural distribution area in southeast Spain. IAWA J. 2015, 36, 22-35. [CrossRef]

42. Gugerli, F.; Sperisen, C.; Buchler, U.; Brunner, L.; Brodbeck, S.; Palmer, J.D.; Qiu, Y.L. The evolutionary split of Pinaceae from other conifers: Evidence from an intron loss and a multigene phylogeny. Mol. Phylogenet. Evol. 2001, 21, 167-175. [CrossRef] [PubMed]

43. Hart, J.A. A cladistic analysis of conifers: Preliminary results. J. Arnold Arbor. 1987, 68, 269-307. [CrossRef]

44. Price, R.A.; Olsen-Stojkovich, J.; Lowenstein, J.M. Relationships among the genera of Pinaceae: An immunological comparison. Syst. Bot. 1987, 12, 91-97. [CrossRef]

45. Greguss, P. Similar xylotomy and leaf-epidermis of the Pseudotsuga and new genus Cathaya. Bot. Közlemények 1970, 57, 51-55.

46. Greguss, P. Xylotomy of the Living Conifers; Akadémiai Kiadó: Budapest, Hungary, 1972; p. 379.

47. Wang, X.Q.; Han, Y.; Hong, D.Y. PCR-RFLP analysis of the chloroplast gene trnK in the Pinaceae, with special reference to the systematic position of Cathaya. Isr. J. Plant Sci. 1998, 46, 265-271. [CrossRef] 